\title{
TIME-RELATED EFFICACY OF LIVER CELL ISOGRAFTS IN FULMINANT HEPATIC FAILURE ${ }^{1}$
}

\author{
V. CUERNAS-MONS, ${ }^{2}$ J. A. CIENFUEGOS, P. MAGANTO, A. GOLITSIN, G. EROLES, J. \\ CASTILLO-OLIVARES, AND J. M. SEGOVIA DE ARANA
}

\author{
Departments of Surgery and Medicine, Clinica Puerta de Hierro, Autonomous University, \\ Madrid, Spain
}

\begin{abstract}
We and others have reported that dispersed liver cells transplanted into the spleen parenchyma of syngeneic rata remained functional and viable for a long time. This report describes our resulta with hepatocellular transplantation as a therapeutic method in a model of fulminant hepatic failure (FHF) in the rat.

60 male Sprague-Dawley rata weighing 200-250 g were used. The FHF was reached through an Eck's fistula with 2/3 hepatectomy at the same time. This model produced lethal hepatic failure in a highly reproducible manner. Liver cells were isolated by the collagenase method. 40x10" hepatocytes suspended in Hanks' balanced salt solution were transplanted into the spleen parenchyma $24 \mathrm{hr}$ before (group 1), at the same time as (group 2), and $24 \mathrm{hr}$ after (group 3) FHF was achieved. Additional sham-operated animals (groups 4 and 5) and a control group (group 6) were used.

The hepatocellular transplantation markedly increased the survival of the animals with induced FHF to $80 \%$ (group 1) and 60\% (group 2)-but not in group 3 (20\%),-compared with 10\% in the control group.

This study shows that dispersed liver cells transplanted into the spleen can provide sufficient support to allow animals with lethal hepatic failure to survive and recover. Nevertheless the efficacy of transplantation is a time-related phenomenon with the FHF induction.
\end{abstract}

Numerous methods to provide hepatic support have been tried, but most of them cannot assume the functions performed by the liver. Current research efforts are directed toward developing procedures that can provide the most complete metabolic support, but it is unlikely that techniques other than those providing functioning liver cells will be adequqate for anything but incomplete support, so a complete satisfactory method of artificial liver support is not available at present.

It has been reported elsewhere that cell suspensions of syngeneic hepatocytes given i.p. or injected directly into the portal vein can significantly improve the survival rate of rats with different models of drug-induced acute fulminant hepatic failure $(\mathrm{FHF})^{3}(1,2)$. Mito et al. (3) and Kusano and Mito (4) have reported that the spleen is the most suitable site for the long-term survival of transplanted hepatocytes that originating from normal adult rat liver.

In this report we studied the ability of synegeneic hepatocytes, transplanted at different times, to improve the survival rate of rata with experimental FHF, using the spleen as the site of implantation.

\footnotetext{
${ }^{1}$ This work was supported by Grant 378/81 awarded by the Fondo Investigaciones Sanitarias de la Seguridad Social.

2 Address correspondence to: Valentin Cuervas-Mons, M.D., Department of Medicine, Clinica Puerta de Hierro, Universidad Autonoma de Madrid, S. Martín de Porres 4, Madrid 35 Spain.

${ }^{3}$ Abbreviation used in this article: FHF, fulminant hepatic failure.
} 


\section{MATERIALS AND METHODS}

Animals. Inbred male Sprague-Dawley rats (200-250 g) were used as hepatocyte recipients, donors, and controls in all experiments. The animals were fed ground standard rat chow ad libitum. Water was provided freely throughout. They were housed in temperature controlled rooms at $25 \mathrm{C}$.

Preparation of hepatocytes. A modification of the collagenase digestion method developed by Berry and Friend (5) was used to isolate hepatocytes. The donor rata were anesthetized with ether. Midline laparotomy was then performed. The portal vein was cannulated with a No. 18 Abott catheter. The cannula was then connected to an infusion system powered by a perfusion pump, and perfusion with Ca" free Hanks' balanced salt solution at $37 \mathrm{C}$ was begun at $20 \mathrm{ml} / \mathrm{min}$ for 10 min. The perfusate was then changed to a $0.05 \%$ solution of collagenase, which was recirculated for 30 min. The $\mathrm{pH}$ in the perfusate was maintained at 7.4, infusing $2.8 \% \mathrm{NaCO}_{3} \mathrm{H}$ when necessary. The liver was removed, the capsule was incised, and the parenchymal cells were separated from the hapatic connective and vascular structures by raking with a stainless steel comb. The resultant mash was incubated at $37 \mathrm{C}$ with $30 \mathrm{ml}$ of a $0.05 \%$ collagenase solution for $15 \mathrm{~min}$. The cells were washed three times. Aliquots were taken for cell count in a hematocytometer. Viability was determined by Trypan blue exclusion. The final cell suspension contained 85-95\% intact hepatocytes.

Trarzsplantation of isolated hepatocytes. Hepatocellular transplantation was carried out at laparotomy by direct injection of $0.5 \mathrm{ml}$ of the hepatocyte suspension through a 25-gauge needle into the splenic parenchyma of syngeneic rats. Each recipient rat was transplanted with $40 \times 10^{6}$ intact parenchymal hepatocytes. Leakage from the site of injection was minimized by clipping.

Induction of fulminant hepatic failure. Liver failure was induced by a combination of partial hepatectomy followed by an end-to-side portacaval shunt, under ether anesthesia. Concurrent 2/3 partial hepatectomy, as described by Higgins and Anderson (6), was performed. The end-toside portacaval shunt was constructed according to the method of Lee et al. (7). From our experience, this FHF model had a high mortality and was quite accurate, as described elsewhere (8).

In this study, FHF was induced using the surgical procedure previously described in 60 rata. The experimenta were performed during 10 consecutive days, at a rate of six rats per day. Rats were divided at random into six groups as follows:

Group 1: Hepatocytes transplanted into spleen $24 \mathrm{hr}$ before surgically induced FHF (n:10).

Group 2: Simultaneous transplant and surgery (n:10).

Group 3: Transplant 24 hr after surgery (n:10).

Group 4: Hanks' balanced salt solution injected into the spleen at the time of surgery (n:10).

Group 5: Hanks' balanced salt solution injected into spleen $24 \mathrm{hr}$ after surgery (n:10).

Group 6: Surgically induced FHF alone (n:10).

All surviving animals were killed 2 weeks after FHF. The livers and spleens of all rats operated upon were examined histologically. All tissues were fixed in Bouin's solution, sectioned, and stained with hematoxylin and eosin.

Statistics. The chi-square test was employed for statistical study, with $P<0.05$ being considered the minimum leve) of significance.

\section{RESULTS}

The number of rats that survived in the various groups treated with and without hepatocellular transplantation is summarized in Figure 1. Over a two-week period, a significantly higher number $(P<0.01)$ of operated rats survived in the syngeneic hepatocellular recipients (groups 1 [8/10] and 2 [6/ 10] when compared with groups 3, 4, 5 and $6[2 / 10,1 / 10,0 / 10$, and 1/10, respectively]). There was no significant difference between groups 1 and 2 . No spontaneous 
deaths occurred in any group after 4 days. All surviving animals were killed after 2 weeks postransplantation.

Histologic analysis of the spleen revealed isolated or grouped hepatocytes dispersed throughout the splenic parenchyma in groups 1, 2, and 3. Hepatic cord structures and deposits of bile pigmentlike material were also observed along with the hepatocytes. Bile ductules were observed in the spleen of hepatocellular recipient rats. Occasionally, binuclear hepatocytes were observed.

\section{DISCUSSION}

Acute liver failure carries a high mortality rate. Current treatments are unsatisfactory and most patients die before the liver has had a chance to recover. Because of the liver's wellknown capacity to regenerate, survival can occur and recovery is possible. This fact has led to the development of various methods of temporary liver support, with no improvement in survival rates in acute hepatic failure $(9,10)$, because of the fact that most of these methods cannot assume all of the complex functions performed by the normal liver. A completely satisfactory method of artificial liver support is not available at present. Auxillary liver transplantation provides the most complete metabolic assistance (11), but this technique is associated with high mortality and morbidity both in clinical and in experimental situations $(12,13)$. Hepatocellular transplantation has been used in the treatment of FHF and its efficacy in increasing the survival rate of rata with experimental acute hepatic failure has recently been demonstrated $(1,2)$. Moreover, hepatocellular transplantation is a relatively simple therapeutic approach to the treatment of FHF; it is minimally invasive and carries little risk - no deaths were observed in normal recipient rats one year after transplantation (14).

Reversal of experimental FHF by portal vein or peritoneal hepatocellular transplants has been reported $(1,2,15,16)$. We have extended this finding to demonstrate the efficacy of syngeneic hepatocytes transplanted directly into the rat spleen in surgically induced FHF. Our experiment shows that dispersed liver cells transplanted directly into the spleen $24 \mathrm{hr}$ before, or at the same time as, injury, can provide sufficient support to allow the majority of syngeneic rats with otherwise lethal acute surgical liver injury to survive while thier own livers recover. The transplant was performed before, during, or after the injury. Although this situation is highly artificial, it allows conclusions to be drawn about the viability of the transplanted hepatocytes. Contrary to previous work using drug-induced models of FHF $(12,15,16)$, the hepatocellular transplantation $24 \mathrm{hr}$ after the injury did not significantly increase the survival rate of operated rats, the explanation for this finding is not clear, and further investigation is necessary. This transplantation seems to work well in rats, but it must preceed or accompany the surgical FHF, clearly a difficult problem in human beings. Further studies of this new therapeutic approach are necessary.

Acknowledgments. We thank S. De Andrea for technical assistance, L. Fernandez for graphics, and I. Rodrigo for secretaria) assistance.

\section{LITERATURE CITED}

1. Sutherland DER, Numata M, Matas AJ, Simmons RL, Najarian JS. Hepatocellular transplantation in acute liver failure. Surgery 1977; 82: 124.

2. Sommer BG, Sutherland DER, Matas AJ, Simmons RL, Najarian JS. Hepatocellular transplantation for treatment of D-Galactosamine induced acute liver-failure in rata. Transplant Proc 1979; 11: 578.

3. Mito M, Ebata H, Kusano M, Onishi T, Hiratsuko M, Saito T. Studies on ectopic liver utilizing hepatocyte transplantation into the rat spleen. Transplant Proc 1979; 11: 85. 
4. Kusano M, Mito M. Observations on the fine structure of longsurvived isolated hepatocytes inoculated into rat spleen. Gastroenterology 1982; 82: 616.

5. Berry MN, Friend DS. High-yield preparation of isolated rat liver parenchymal cells: a biochemical and fine structural study. J Cell Biol 1969; 43: 506.

6. Higgins GM, Anderson RM. Experimental pathology of the liver: restoration of the liver of the white rat following partial surgical removal. Arch Pathol 1931; 12: 186.

7. Lee S, Chadler JG, Broelsch CE, Flamant IM, Orloff MJ. Portal systemic anastomosis in the rat. J Surg Res 1974; 17: 53.

8. Cuervas-Mons V, Golitsin A, Alvarez-Cienfuegos J, Maganto P, Eroles G, Castillo-Olivares JL. Anastomosis portocava término-lateral y hepatectomía del 70\% como modelo experimental de insuficiencia hepática fulminante en rata. Rev Esp Enf Ap Digest (in presa).

9. Saunders SJ, Terblanche J. Prognosis in acute hepatic failure. In: Williams R, Murray-Lyon IM, eds. Artificial liver support. London: Pitman, 1975:217.

10. Saunders SJ, Seggie J, Kirsch RE, Terblanche J. Acute liver failure. In: Wright R, Alberti KGMN, Karran S, Millward-Sadler GH, eds. Liver and biliary disease. London:Saunders, 1979:569.

11. Kuster GGR, Woods JE. Auxiliary liver transplantation in the dog as temporary support in acute fulminating hepatic necrosis. Ann Surg 1972; 176: 732.

12. Huguet C, Bloch P, Opolon P. Traitment des necroses sigues du foie par transplantation hepatique. J Chir 1974; 108: 397.

13. Starzl TE, Koep LJ, Halgrimson CG, et al. Fifteen years of clinical liver transplantation. Gastroenterology 1979; 77: 375.

14. Cuervas-Mons V, Maganto P, Alvarez-Cienfuegos J, et al. Morphology and 99mTc-HIDA functional study of isolated syngeneic hepatocytes transplantad into rat spleen (abstract). Eur Surg Res 1981; 13(suppl): 60.

15. Makowka L, Rotstein LE, Falk RF, et al. Allogeneic and xenogeneic hepatocyte transplantation. Transplant Proc 1981; 13: 855.

16. Sommers BG, Sutherland DER, Simmons RL, Najarian JS. Hepatocellular transplantation for experimental ischemic acute liver failure in doga. J Surg Res 1980; 29: 319. 


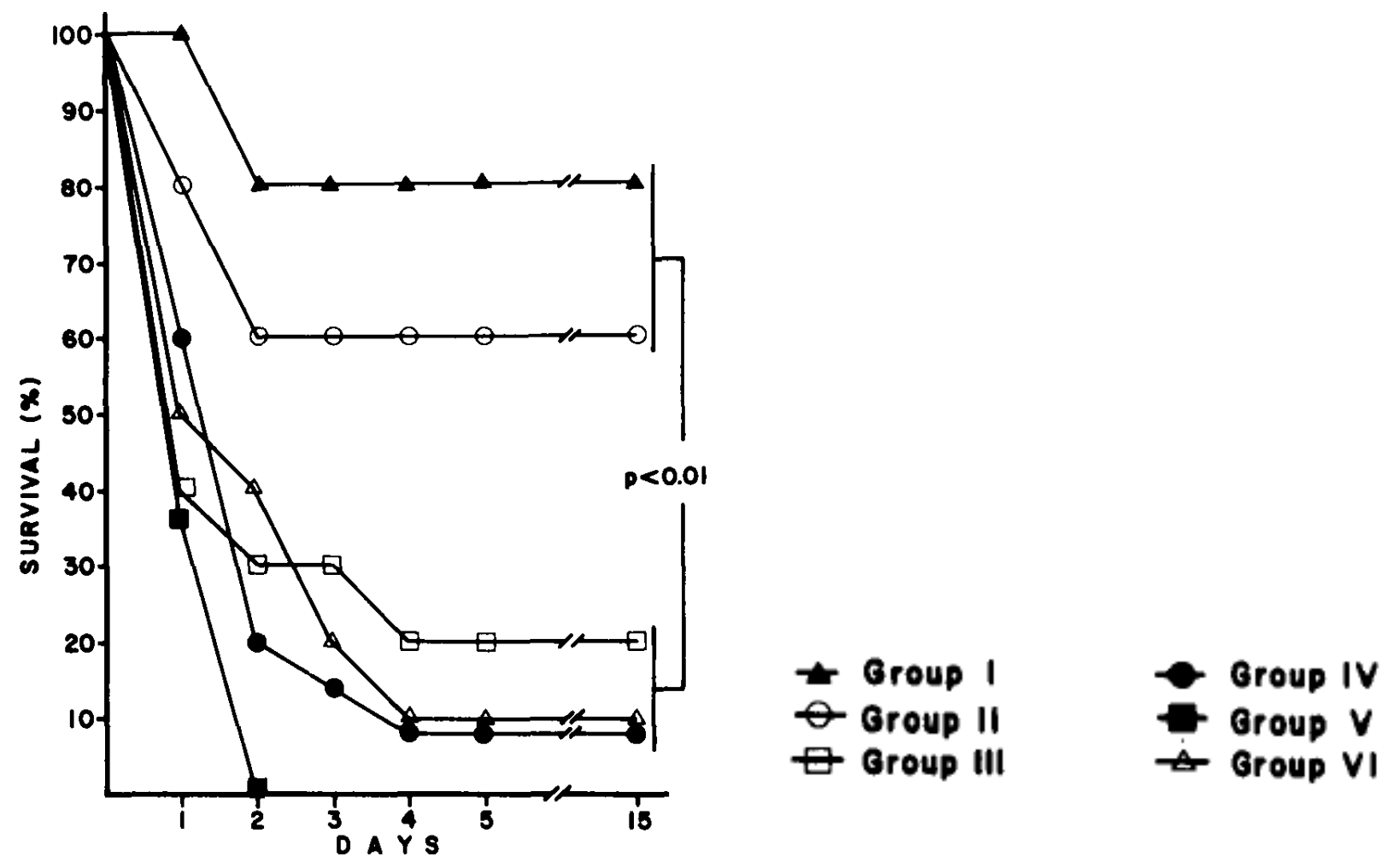

FIGURE 1. Time-related efficacy of hepatocellular transplant in fulminant hepatic failure. Transplantation was carried out $24 \mathrm{hr}$ before (group 1), at the same time (group 2) and $24 \mathrm{hr}$ after the induction of FHF (group 3). Groups 4, 5, and 6 received an injection of Hanks' $24 \mathrm{hr}$ before, at the same time as, and $24 \mathrm{hr}$ after FHF induction, respectively. 